\title{
Tomasz Łysak
}

Uniwersytet Warszawski

https://orcid.org/0000-0002-5476-4917

tlysak@uw.edu.pl

\section{Yolocaust: kapitalizm platform a cyfrowe praktyki upamiętniania Zagłady}

\begin{abstract}
Streszczenie
Upamiętnianie w sieci kojarzy się ze skandalami i gafami, ale wielu twórców treści nie ma intencji obrażania kogokolwiek lub narażenia się na internetowy hejt. Oprócz dotychczasowych metod opisu cyfrowego upamiętniania (analiza treści, porównanie do tradycyjnej pamięci medialnej) artykuł wykorzystuje netnografię, to jest obserwację i analizę zachowań internautów, a także przygląda się ekosystemowi mediów cyfrowych w kontekście kapitalizmu platform. Materiał badawczy to strona internetowa yolocaust.de, fotografie Auschwitz Tomasza Lewandowskiego oraz heavymetalowe występy ocalałej Inge Ginsberg.
\end{abstract}

\section{Słowa kluczowe}

Yolocaust, kapitalizm platform, cyfrowe upamiętnianie Zagłady, Auschwitz, YouTube.com, Tomasz Lewandowski, Inge Ginsberg

\begin{abstract}
Online commemorations are associated with scandals and faux pases, but many content creators do not intend to offend anybody or become an object of online hate. Aside the existing methods of describing digital commemorations (content analysis, comparisons with the traditional media memory), the article makes use of netnography, that is observation and analysis of Internet users' behavior. It also examines the ecosystem of the digital media in the context of platform capitalism. The research materials are: the yolocaust.de website, photographs of Auschwitz by Tomasz Lewandowski, and survivor Inge Ginsberg's heavy metal performances.
\end{abstract}

\section{Key words}

Yolocaust, platform capitalism, digital Holocaust commemoration, Auschwitz, YouTube.com, Tomasz Lewandowski, Inge Ginsberg

Na początku lat dziewięćdziesiątych XX w. uważano, że dzieci ocalałych, należące do tzw. drugiego pokolenia, zastąpią świadków w sztafecie upamiętniania. Członkowie rodzin ocalałych, obecnie także wnuki i prawnuki ocaleńców, nie porzucili tej istotnej społecznie praktyki, pojawiła się jednak inna grupa aktorów pamięci. Po upowszechnieniu się internetu Web 2.0 pod koniec pierwszej deka- 
dy XXI w. użytkownicy narzędzi cyfrowych i mediów społecznościowych przywołują Zagładę, kierując się chwilowymi modami, chęcią zdobycia widzialności lub innymi motywami. Twórcy treści zamieszczają materiały audiowizualne, wizualne lub audialne na stronach internetowych, blogach i profilach w mediach społecznościowych. Zaliczamy ich do grupy prosumentów (tzn. producentów a zarazem konsumentów kultury cyfrowej), w kontekście upamiętniania trafne są określenia influencerzy lub popularni historycy ${ }^{1}$. Chociaż w przestrzeni medialnej upamiętnianie w sieci kojarzone jest zwykle z różnorakimi skandalami, gafami ${ }^{2}$ i brakiem wyczucia, wielu twórców włącza się w upamiętnianie bez intencji obrażania kogokolwiek lub narażania się na gniew internetowego tłumu. Posiedli oni umiejętność tworzenia treści atrakcyjnych wizualnie oraz zarządzania widzialnością na konkretnej platformie. Adresując przekaz do internautów obserwujących ich profile, żywią nadzieję, że algorytmy pomogą im dotrzeć do szerokiej publiczności. Niektórzy z nich to profesjonaliści, czerpiący dochód z regularnego zamieszczania nowych materiałów. Większość para się „pracą aspiracyjną" ${ }^{3}$, produkując treści bez żadnego wynagrodzenia, w oczekiwaniu na odroczoną gratyfikację. To zjawisko nazwano „pracozabawą” (playbor), czyli „połączeniem radosnej przyjemności i produktywnej pracy [...], hybrydą placu zabaw i fabryki”". W opinii Grega Goldberga cyfrowi robotnicy „przekształcają hobby w pracę", czego skutkiem jest podejmowanie skądinąd pożądanych działań w sieci ${ }^{5}$. Powszechna zgoda dotycząca moralnej wartości upamiętniania Zagłady sprawia, że taka aktywność wiąże się z obietnicą nagrody w sferze symbolicznej. Bez wątpienia w internecie pojawiają się inne formy upamiętniania: strony wspominające mieszkańców przedwojennych sztetli, oficjalne profile instytucji muzealnych lub fikcyjne profile postaci historycznych w mediach społecznościowych ${ }^{6}$, nastawione na edukację historyczną. Dopasowują one tradycyjne formy upamiętniania do środowiska cyfrowego, wykorzystując takie formaty jak kroniki, kalendaria wydarzeń, galerie fotografii lub encyklopedie. Ich

\footnotetext{
${ }^{1}$ Jerome de Groot, Consuming History. Historians and Heritage in Contemporary Popular Culture, London: Routledge, 2016.

${ }^{2}$ Tomasz Łysak, Kultura popularna [w:] Reprezentacje Zagłady w kulturze polskiej (19392019), t. 2: Problematyka Zagłady w sztukach wizualnych i popkulturze, red. Sławomir Buryła, Dorota Krawczyńska, Jacek Leociak, Warszawa: Wydawnictwo IBL PAN, 2021, s. 594-596.

${ }^{3}$ Brooke Erin Duffy, The Romance of Work. Gender and Aspirational Labour in the Digital Culture Industries, „International Journal of Cultural Studies” 2016, t. 19, nr 4, s. 441-457.

${ }^{4}$ Yves Citton, The Ecology of Attention, Oxford: Polity, 2016, s. 65.

${ }^{5}$ Greg Goldberg, Antisocial Media. Anxious Labor in the Digital Economy, New York: NYU Press, 2018.

${ }^{6}$ Chodzi o akcję „Listy do Henia” (żydowskiego chłopca, zamordowanego na Majdanku) zapoczątkowaną w przestrzeni miejskiej Lublina i przeniesioną do Facebooka (Diana I. Popescu, Eulogy of a Different Kind: 'Letters to Henio' and the Unsettled Memory of the Holocaust in Contemporary Poland, „Holocaust Studies: A Journal of Culture and History” 2019, t. 25, nr 3, s. 273-299).
} 
celem jest przede wszystkim podtrzymanie pamięci o Zagładzie (lub jej zanegowanie w przypadku treści publikowanych przez negacjonistów). Omawiane tutaj platformy internetowe służą przede wszystkim promocji twórców podejmujących powszechnie rozpoznawalny temat.

Niemożliwe jest zrozumienie fenomenu cyfrowego upamiętniania Zagłady bez wykorzystania narzędzi do badania przestrzeni sieci lub z pominięciem refleksji nad nowym ekosystemem mediów cyfrowych ${ }^{7}$. W związku z tym analizie treści powinna towarzyszyć próba zrozumienia dostępnych metadanych (liczby subskrypcji i odtworzeń, komentarzy i innych interakcji z twórcą) oraz rozpoznanie konwencji typowych dla danej platformy. Na przykład widzowie filmów na platformie YouTube bez problemu rozpoznają (anty)poradniki i recenzje. $\mathrm{Z}$ tego powodu relacje influencerów z odwiedzin Państwowego Muzeum Auschwitz-Birkenau zawierają objaśnienia, jak zorganizować przejazd z Krakowa do Oświęcimia, czego spodziewać się podczas oprowadzania z grupą, a czego podczas indywidualnego zwiedzania ${ }^{8}$. Influencerzy apelują do odwiedzających Muzeum, aby powstrzymali się przed zachowaniami niezgodnymi z oficjalną polityką zwiedzania lub godzącymi w ich poczucie decorum. Jak podkreśla Victoria Grace Walden, instytucjonalne zasady upamiętniania są albo nieznane twórcom amatorom, albo nie biorą oni ich sobie do serca ${ }^{9}$.

Podstawowa trudność badania cyfrowego upamiętniania polega na odnalezieniu materiału badawczego: $\mathrm{z}$ jednej strony na uwagę zasługują treści o szerokim zasięgu (stąd Yolocaust w tytule), z drugiej zaś produkcje wartościowe poznawczo i o wysokich walorach estetycznych docierają do użytkowników platform dla specjalistów. W niniejszym artykule przyjrzę się trzem przykładom upamiętniania w sieci: projektowi Yolocaust niemiecko-izraelskiego komika Shahaka Shapiry, fotografiom Tomasza Lewandowskiego na stronie lensculture. com oraz „deathmetalowej babci” - dziewięćdziesięciokilkuletniej wokalistce zespołu metalowego, ocalałej z Zagłady Inge Ginsberg. 0 projekcie Yolocaust dowiedziałem się dzień po jego uruchomieniu, występy Ginsberg odkryłem pod-

${ }^{7}$ Takie podejście zakłada połączenie badań nad produkcją i konsumpcją mediów cyfrowych, jak też obiegiem tych treści w mediach społecznościowych, w celu rekonstrukcji procesu tworzenia znaczeń tekstów medialnych. C.W. Anderson, Practice, Interpretation, and Meaning in Today's Digital Media Ecosystem, „Journalism \& Mass Communication Quarterly” 2020, t. 97, nr 2, s. 342-359.

${ }^{8}$ Samodzielne zwiedzanie pozwala skupić się na filmowaniu, emocjach i estetyce przekazu. Zwiedzanie z przewodnikiem ma tę zaletę, że nagrywanym obrazom towarzyszy narracja przewodnika (o ile przebije się przez hałas grupy, bo zwiedzający mają słuchawki na uszach). Zob. Tomasz Łysak, Vlogging Auschwitz. New Players in Holocaust Commemoration, „Holocaust Studies: A Journal of Culture and History" 2021, w przygotowaniu.

${ }^{9}$ Victoria Grace Walden, Introduction: Defining the Digital in Digital Holocaust Memory, Education, and Research [w:] Digital Holocaust Memory, Education and Research, red. Victoria Grace Walden, London: Palgrave MacMillan, brak paginacji, w przygotowaniu. Dziękuję redaktorce za udostępnienie mi roboczego maszynopisu książki. 
czas kwerendy na temat muzyki popularnej i Holokaustu. Jako użytkownik platformy lensculture.com postanowiłem sprawdzić, czy znajdują się tam fotografie upamiętniające Zagładę. Na ten wybór można spojrzeć z kilku perspektyw. Po pierwsze z punktu widzenia wykorzystanych platform, odpowiednio strony internetowej Shapiry, portalu społecznościowego dla profesjonalnych fotografów oraz platformy YouTube. Po drugie wybrane przykłady to historie sukcesu mierzonego różnymi miarami: wiralności oraz wyróżnienia przez panel ekspertów w międzynarodowym konkursie. Po trzecie projekty te wykorzystują mechanizmy zarządzania uwagą i skupiania emocji, typowe dla działań w sieci.

Materiał do analizy zebrałem, wykorzystując metodę netnografii, zaproponowaną przez Roberta Kozinetsa w książce Netnografia: badania etnograficzne online $^{10}$, a następnie rozwijaną $\mathrm{w}$ kolejnych publikacjach ${ }^{11}$. Netnografia służy badaniu zachowań użytkowników sieci pod kątem ich sprawczości w tym środowisku, tę perspektywę uzupełniono o podejście posthumanistyczne, „włączając [w nie] obiekty obdarzone sprawczością, takie jak boty, algorytmy i inteligentne agensy"12. Ta metoda umożliwia rekonstrukcję motywów poszczególnych twórców, ich profilu w sieci (w tym śladów zostawianych na innych platformach oraz wtórnego obiegu treści bez wiedzy twórcy lub niezgodnie z jego/jej intencjami) oraz analizę metadanych. Korzystałem wyłącznie z treści i metadanych dostępnych w sieci zarówno na danej platformie, jak i w innych serwisach, nie wchodząc $\mathrm{w}$ interakcję $\mathrm{z}$ twórcami. Przyjąłem następującą definicję metadanych: „Metadane to sąd o obiekcie-nośniku potencjalnej informacji”"13. Za każdym razem należy rozpoznać ich rangę i typ, np. platformy fotograficzne publikują dane o sprzęcie oraz jego ustawieniach (czasie ekspozycji, przysłonie, światłoczułości wyrażonej w ISO itp.). Popularne platformy udostępniają statystyki wejść/odtworzeń, polubień oraz komentarze. Metadane tego typu są miernikiem sukcesu w kapitalizmie uwagi ${ }^{14}$, ich publiczna dostępność różni te platformy od np. stron internetowych, gdzie udostępniane są twórcom/administratorom, a nie publiczności. Szerszym kontekstem badania jest „kapitalizm platform”, tj. nowa forma ekonomii oparta na wydobywaniu danych z aktywności użytkowników sieci w celu sprzedania ich z zyskiem, po wcześniejszej obróbce, podmiotom ze-

${ }^{10}$ Robert V. Kozinets, Netnografia: badania etnograficzne online, tłum. Maja Brzozowska-Brywczyńska, Warszawa: Wydawnictwo Naukowe PWN, 2012.

${ }^{11}$ Netnography Unlimited, red. Robert V. Kozinets, Rossella Gambetti, New York: Routledge, 2020.

${ }^{12}$ Robert V. Kozinets, Daiane Scaraboto, Marie-Agnès Parmentier, Evolving Netnography. How Brand Auto-netnography, a Netnographic Sensibility, and More-than-human Netnography Can Transform Your Research, „Journal of Marketing Management” 2018, t. 34, nr 3/4, s. 232.

${ }^{13}$ Jeffrey Pomerantz, Metadata, Cambridge, MA: The MIT Press, 2015, s. 26.

${ }^{14}$ Jedną z zasad tej ekonomii jest „nadawanie wartości poprzez skupianie uwagi”: „zwykłe patrzenie na obiekt to praca, zwiększająca jego wartość" (Citton, The Ecology of Attention..., s. 47). 
wnętrznym ${ }^{15}$. Nick Srnicek nie pozostawia złudzeń, platformy internetowe powstają w celu zdominowania rynku: „Nie wystarcza im jedynie posiadanie informacji, ich celem jest zawładnięcie infrastrukturą społeczeństwa"16. Ekonomia cyfrowa stała się także kluczowa dla współczesnej gospodarki, a „,jej upadek byłby ekonomiczną katastrofą"17. Niniejszym chciałbym postawić pytanie o wpływ platform internetowych i ekonomii uwagi na cyfrowe praktyki upamiętniania Zagłady.

\section{Yolocaust - mechanizmy zarządzania uwagą w sieci}

Neologizm „Yolocaust” powstał z połączenia akronimu YOLO ${ }^{18}$ (You only live once, tj. żyje się tylko raz) ze słowem Holokaust; pierwotna konotacja nie jest znana. Może chodzić o hiperbolizację, typową dla slangu, lub o krytyczny dystans do nazywanego zjawiska. Projekt Shahaka Shapiry atakuje reprezentacje użytkowników mediów społecznościowych uchwycone w przestrzeni pomnika Zamordowanych Żydów Europy w Berlinie, wmontowane następnie w historyczne zdjęcia przedstawiające „ofiary Holokaustu”19. Projekt uruchomiono 18 stycznia 2017 r., od razu stał się wiralem (opisanym w gazetach „Guardian” i „New York Times"). Nie wszystkie fotografie to selfie, jak przedstawiały to media ${ }^{20}$. Źródłem tego nieporozumienia jest opis na stronie yolocaust.de, Shapira znalazł te wizerunki na Facebooku, Instagramie, Tinderze i Grindrze. W istocie zaledwie trzy zdjęcia z dwunastu na pewno są autoportretami zrobionymi smartfonem ${ }^{21}$

${ }^{15}$ Nick Srnicek, Platform Capitalism, Cambridge: Polity, 2017.

${ }^{16}$ Ibidem, s. 92.

${ }^{17}$ Ibidem, s. 5.

${ }^{18}$ Kanadyjski raper Drake wychwala to podejście do życia, odrzucające konsekwencje społecznie stygmatyzowanych zachowań, w utworze The Motto (z gościnnym udziałem Lila Wayne'a) z listopada 2011 r. Zob. Calvin John Smiley, From Silence to Propagation. Understanding the Relationship between „Stop Snitchin” and „YOLO”, „Deviant Behavior” 2015, t. 36, nr 1, s. 1-16.

${ }^{19}$ To częsty błąd atrybucji zdjęć zbrodni wojennych, gdyż na ich podstawie nie sposób zidentyfikować ofiar, uchwyconych w abjektalnej formie jako stosy zwłok w wyzwolonych obozach. Bezpieczniej byłoby mówić o „ofiarach obozów” niż o „ofiarach Holokaustu”, chyba że mówimy o konkretnym zdjęciu nazistowskich katów oraz zwłokach zamordowanych przez nich Żydów.

${ }^{20}$ O Yolocauście jako „oskarżeniu kultury selfie” pisze Marcin Watemborski, Yolocaust to selfie na szczq̨tkach ofiar holocaustu. Mocna seria zdjęć obnażająca brak szacunku dla ludzkiej tragedii, „Fotoblogia”, brak daty, https://fotoblogia.pl/10144,yolocaust-co-jest-wazniejszeselfie-czy-szacunek-dla-ludzkiej-tragedii (dostęp 6 VII 2021 r.). Hubert Orzechowski zaleca refleksję zamiast bezmyślnego pstrykania selfie - Yolocaust. Pomyśl, zanim zrobisz selfie, „Newsweek”, 20 I 2017, https://www.newsweek.pl/kultura/wydarzenia/yolocaust-co-tojest-selfie-w-miejscach-pamieci-zaglady/1we1mkr (dostęp 6 VII 2021 r.).

${ }^{21} \mathrm{O}$ historii autoportretu i usieciowieniu tej formy autoreprezentacji zob. Nicholas Mirzoeff, Jak zobaczyć świat, tłum. Łukasz Zaremba, Kraków-Warszawa: Wydawnictwo Karakter, Muzeum Sztuki Współczesnej w Warszawie, 2016, s. 44-46 i n. 
(na dwóch widać tyczkę do selfie, a na trzecim najprawdopodobniej znalazła się poza kadrem). Inne to pozowane portrety, zdjęcia w atletycznych pozach (kalistenika lub joga) bądź fotografia grupowa. W lewym dolnym rogu zdjęć znajdujemy metadane: lokalizację, hashtagi, emotikony, reakcje (kciuki w górę lub serduszka) oraz liczbę polubień w momencie „przechwycenia” zdjęcia. Fotografie przycięto do formatu przypominającego kwadrat znany z Instagrama (10:9, a nie 1:1). Najechanie kursorem na zdjęcie uruchamia animowane przejście do kompozytowego obrazu, w którym współczesne tło zastąpiono archiwalną fotografią z wyzwalania obozów (np. Dachau, w tym ikoniczne zdjęcie Eli Wiesela z innymi więźniami) lub ujęciami masowych grobów. Forma graficzna projektu to udosłownienie żartu $\mathrm{z}$ opisu pierwszego zdjęcia na stronie: dynamiczny przeskok między rzędami betonowych bloków internauta podpisał „skacząc po martwych Żydach". Obrazy z mediów społecznościowych poddano desaturacji w programie graficznym, po dwóch sekundach od uruchomienia animacji kolory znikają, a wycięte sylwetki internautów wtapiają się w tło archiwalne. W momencie uruchomienia strony ${ }^{22}$ pojawiły się tam instrukcje, jak usunąć z niej własne zdjęcie (okazując skruchę w e-mailu). Ostatnie zdjęcie Shapira zdjął z witryny po tygodniu, obecnie można tam przeczytać jedynie archiwalny komentarz satyryka (po angielsku i niemiecku) oraz wybrane reakcje internautów. Niemniej obietnica przywrócenia twarzy internautom postawionym pod pręgierzem czy wręcz wystawionym na lincz przez „tłum z widłami”"23 była pusta. Po pierwsze zrzuty ze strony dostępne są $\mathrm{w}$ archiwum internetowym Wayback Machine, w którym dzień po dniu (lub niemalże godzina po godzinie) śledzimy zmiany udostępnionych treści. Po drugie wyszukiwarka obrazów Google nadal odnajduje te fotografie, zgodnie z ambicją tej firmy, aby zdominować dostęp do informacji. Mechanizm prześladowania młodych ludzi przez powszechnie dostępne zmediatyzowane wspomnienia ich (nie)chlubnej przeszłości Kate Eichhorn nazwała „końcem zapominania”"24. Shoshana Zuboff ocenia w podobnym

${ }^{22}$ Wayback Machine podaje, że domenę yolocaust.de zarejestrowano w 2013 r. Jeśli Shapira wykupił ten adres, to wypełnił go treścią dopiero w styczniu 2017 r. Narzędzie Google Trends, służące do analizy wyszukiwań w tej przeglądarce, zauważyło „yolocaust” w grudniu 2012 r. Po wyraźnym „piku” zainteresowania w styczniu 2017, wyszukiwania spadły do wcześniejszego, niskiego poziomu już w kwietniu tegoż roku. Słowo najczęściej wyszukiwano w Niemczech i Austrii, Polska znalazła się na szóstym miejscu, https://trends.google.pl/ trends/explore?date=all\&q=yolocaust (dostęp 9 VII 2021 r.). Yolocaust to także tytuł niszowego, niemieckiego utworu hiphopowego z 2014 r., niepodejmującego tematów historycznych. Jhony Kaze Feat Snippah, „Yolocaust” - Prod by Essem - Offizielles HD Video, „YouTube”, 20 III 2014, https://www.youtube.com/watch?v=KXZgq7QDeXY liczba wyświetleń 8513 (dostęp 9 VII 2021 r.).

${ }^{23}$ Kristine L. Gallardo, Taming the Internet Pitchfork Mob. Online Public Shaming, the Viral Media Age, and the Communications Decency Act, „Vanderbilt Journal of Entertainment and Technology Law" 2017, t. 19, nr 3, s. 721-746.

${ }^{24}$ Kate Eichhorn, The End of Forgetting. Growing up with Social Media, Cambridge, MA: Harvard University Press, 2019. 
tonie, że cyfrowa rewolucja zatrzymała proces starzenia się informacji i pojawia się ona, zawsze świeża, w naszej cyfrowej tożsamości ${ }^{25}$. Shapira nie podał imion i nazwisk użytkowników, poprzestając na ich wizerunkach, lecz oprogramowanie do rozpoznawania twarzy bez problemu rozpozna osoby na zdjęciach. Algorytmy coraz trafniej przewidują starzenie się twarzy, więc nawet w przyszłości sportretowani mogą ponosić konsekwencje nieprzemyślanego udostępnienia wizerunku.

Yolocaust przejmuje zagospodarowany wcześniej afekt wymierzony w „narcystyczną kulturę selfie”, jak w przypadku „uśmiechniętego selfie” z Państwowego Muzeum Auschwitz-Birkenau (czerwiec 2014 r.) amerykańskiej nastolatki Breanny Mitchell ${ }^{26}$. Niespodziewany, negatywny rozgłos dał jej sposobność publicznego objaśnienia swojej radości. Mitchell planowała wizytę z przedwcześnie zmarłym ojcem, na zdjęciu cieszyła się ze spełnienia wspólnego marzenia. Nieskrywany zachwyt ściągnął na nią gniew postronnych, obroniła jednak własne intencje ${ }^{27}$. W tym samym czasie kalifornijski DJ występujący pod pseudonimem MAKJ zamieścił „inspiracyjną” fotografię z berlińskiego pomnika, usuniętą jednak po obraźliwych komentarzach wytykających muzykowi brak wiedzy historycznej ${ }^{28}$. Oprócz wypróbowanej strategii ataku na narcystycznych turystów Shapira wykorzystał mechanizm „publicznego zawstydzania w sieci”29, stawiając się w roli „samozwańczego stróża prawa w internecie” (słowo digilante to neologizm, zrost przymiotnika digital i rzeczownika vigilante) ${ }^{30}$. Taka osoba wskazuje patologię, z którą się nie zgadza, oczekując, że internauci zasypią winnego negatywnymi komentarzami. Ma to skłonić zaatakowanego do publicznych przeprosin i porzucenia skrytykowanej praktyki. Początkowo chodziło o samodzielną rejestrację fotograficzną piętnowanych zachowań, np. w celu wzbudzenia świadomości ekologicznej podczas suszy w Kalifornii w $2015 \mathrm{r}^{31}$ Shapira krytykuje zastane wizerunki, aby wymóc skruchę u sfotografowanych. Tę praktykę określono jako „kultura calloutu”, w której publiczna konfrontacja następu-

${ }^{25}$ Shoshana Zuboff, Wiek kapitalizmu inwigilacji: walka o przyszłość ludzkości na nowej granicy władzy, tłum. Alicja Unterschuetz, Poznań: Zysk i S-ka, 2020, s. 88.

${ }^{26}$ Rachel E. Dubrofsky, Frayed Edges. Selfies, Auschwitz, and a Blushing Emoticon, „a/b: Auto/Biography Studies" 2018, t. 33, nr 3, s. 595-603.

${ }^{27}$ Ibidem, s. 597.

${ }^{28}$ [brak autora], MAKJ Causes Uproar With Controversial Photo Taken at Berlin Holocaust Memorial, „Thissongslaps.com”, 28 VIII 2014, https://www.thissongslaps.com/2014/08/ makj-causes-uproar-with-controversial-photo-taken-at-berlin-holocaust-memorial/ (dostęp 12 VII $2021 \mathrm{r}$ ).

${ }^{29}$ Gallardo, Taming the Internet Pitchfork Mob..., s. 721-746.

${ }^{30}$ Zjawisko „wymierzania sprawiedliwości w sieci” (digilantism) piętnuje zachowania kryminalne oraz niepenalizowane przez żaden kodeks karny lub regulamin. Zob. Tom Sorell, Scambaiting on the Spectrum of Digilantism, „Criminal Justice Ethics” 2019, t. 38, nr 3, s. 153-175.

${ }^{31}$ Tara Milbrandt, Caught on Camera, Posted Online. Mediated Moralities, Visual Politics and the Case of Urban 'Drought-Shaming', „Visual Studies” 2017, t. 32, nr 1, s. 3-23. 
je po publikacji polaryzujących lub obraźliwych treści w mediach społecznościowych. W kontekście upamiętniania Zagłady wystarczy wspomnieć o reakcjach na selfie Mitchell ${ }^{32}$.

Po osiągnięciu celu komik przestał aktualizować stronę. Dowiadujemy się tam, że w pierwszym tygodniu liczba odwiedzających wyniosła dwa i pół miliona, odnaleźli się wszyscy sfotografowani, którzy usunęli zdjęcia ze swoich profili. Większość opublikowanych wiadomości zawiera wyrazy zrozumienia dla intencji twórcy, zdarza się hejt wobec niego oraz życzenia, aby fotografujący się trafili do obozu koncentracyjnego. Yolocaust nie wymaga obecnie moderowania (treści umieszczano na stronie po wcześniejszej akceptacji). Wykorzystanie narzędzi do archiwizacji stron internetowych i analizy treści (Wayback Machine i Google Trends) umożliwiło rekonstrukcję chronologii projektu. Analiza ikonograficzna wykazała, że klasyfikacja fotografii jako selfie jest w większości błędna.

Shapira narzuca patos zwiedzającym, co różni go od projektanta monumentu. Zdaniem Petera Eisenmana forma pomnika zachęca zarówno do zadumy, jak i zabawy, a geograficzny dystans do miejsc zbrodni sprawia, że nie jest to miejsce uświęcone cierpieniem. Christoph Bareither postrzega fotogeniczność pomnika jako przyczynę jego popularności w mediach społecznościowych ${ }^{33}$. Po przeprowadzeniu analizy cyfrowych wizerunków badacz podkreśla, że fotografowanie siebie „może odgrywać istotną rolę w tworzeniu osobistych doświadczeń i dzieleniu się nimi" ${ }^{34}$. Krytycy takich praktyk dostrzegają powierzchowną interakcję z miejscem pamięci, w której opłakiwanie ofiar zastąpiono „narcystycznymi aktami autoreprezentacji” 35 . Shapira wybrał cel łatwy do realizacji (niewielu sfotografowanych, niskie ryzyko utraty wizerunku, wysoce prawdopodobna sympatia i prawie pewny współudział internautów). Stygmatyzacja „patologicznych" wizerunków odbyła się kosztem ich bohaterów, postawionych w sytuacji bez wyjścia i wystawionych na atak nieznanych im ludzi. Shapirze należy się uznanie za sprawne wykorzystanie mechanizmów w sieci, jednakże jego pomysł oceniam jako nieetyczny. Łatwiej zaatakować wizerunki - świadectwa niefrasobliwego zachowania w miejscu pamięci - niż wejść w polemikę z prawdziwymi wrogami pamięci o Zagładzie.

${ }^{32}$ Imogen Dalziel, Becoming the 'Holocaust Police'? The Auschwitz-Birkenau State Museum's Authority on Social Media [w:] Digital Holocaust Memory...

${ }^{33}$ Christoph Bareither, Difficult Heritage and Digital Media. 'Selfie Culture' and Emotional Practices at the Memorial to the Murdered Jews of Europe, „International Journal of Heritage Studies" 2021, t. 27, nr 1, s. 58.

${ }^{34}$ Ibidem, s. 70.

35 Tobias Ebbrecht-Hartmann, Lital Henig, i-Memory. Selfies and Self-Witnessing in \#Uploading_Holocaust (2016) [w:] Digital Holocaust Memory... 


\section{W poszukiwaniu profesjonalnego wyróżnienia - Auschwitz - Ultima Ratio of the Modern Age Tomasza Lewandowskiego}

Praca przedstawicieli zawodów twórczych straciła na wartości w związku z rozwojem technologii obrazowania oraz powszechnym dostępem do rejestracji obrazu i dźwięku w wysokiej jakości. Dotyczy to w szczególności fotografów, których sytuacja zawodowa pogorszyła się w wyniku „niszczącej innowacji”, to jest zdigitalizowania tej profesji ${ }^{36}$. Fotografowie zmuszeni są do przekierowania uwagi z pracy twórczej na działania promocyjne w sieci w obliczu zmniejszonego zapotrzebowania na ich usługi. Profesjonalni fotografowie oraz amatorzy biorą udział w konkursach fotograficznych. Zwycięstwo pozwala dotrzeć do wielomilionowej grupy odbiorców i uwiarygodnić się w oczach potencjalnych klientów. W tym duchu reklamuje się portal lensculture.com, kusząc obietnicą, że nagrodzone fotografie trafią do „globalnej internetowej publiczności ponad trzech milionów twórców i miłośników fotografii [...] z ponad 160 krajów". Stanie się tak dzięki „konkursom fotograficznym, wystawom w najważniejszych miastach, projekcjom na festiwalach fotograficznych oraz wydawanym książkom"37. Treści na stronie są bezpłatne, a portal zarabia na opłatach od uczestników konkursów ${ }^{38}$.

Wyszukiwarka lensculture.com znalazła 34 projekty opisane słowem kluczowym „Auschwitz” oraz 67 projektów z identyfikatorem „Holocaust”. W obu wyszukiwaniach projekt Tomasza Lewandowskiego Auschwitz - Ultima Ratio of the Modern Age pojawia się na pierwszym miejscu jako zwycięzca konkursu Emerging Talent Awards w $2017 \mathrm{r}^{39}$ Biorąc pod uwagę ekonomię wyróżnienia typową dla mediów społecznościowych, pominąłem inne trafienia ${ }^{40}$. Takie porównanie pozwoliłoby jednak ocenić praktyki wernakularne w sieci ${ }^{41}$. Opisywany

\footnotetext{
${ }^{36}$ Penny Williams, Paula McDonald, Robyn Mayes, The Impact of Disruptive Innovation on Creative Workers. The Case of Photographers, „Creative Industries Journal” 2020, doi.org/10.1 080/17510694.2020.1858707 (dostęp 9 VII 2021 r.).

${ }^{37}$ Zakładka „0 nas” https://www.lensculture.com/about (dostęp 9 VII 2021 r.).

${ }^{38}$ Zgłoszenie jednego zdjęcia jest bezpłatne, opłata obowiązuje za serię. Przed upływem terminu zgłoszeń organizator promuje wybrane fotografie w mediach społecznościowych. W 2017 r. sporządzenie pisemnej opinii o projekcie wliczano jeszcze w cenę udziału. Portal reklamuje konkursy jako długofalowy plan rozwoju kariery fotograficznej i zachęca do wytrwałości.

${ }^{39}$ Konkurs nie ograniczał tematów prac lub wieku uczestników, którzy decydowali, czy ich sława nie ma jeszcze zasięgu międzynarodowego.

${ }^{40}$ To obrazuje proporcje między „zwycięzcami” a „aspirującymi do sukcesu”. Pułapką tej pracy prekaryjnej jest „okrutny optymizm”, zderzenie górnolotnych obietnic sukcesu z realiami codziennej porażki. Zob. Rachel Ashman, Anthony Patterson, Stephen Brown, 'Don't Forget to Like, Share and Subscribe'. Digital Autopreneurs in a Neoliberal World, „Journal of Business Research" 2018, t. 92, s. 474-483.

${ }^{41}$ Praktyki wernakularne znajdują się w centrum zainteresowania korporacji cyfrowych, bo zwiększają ruch w sieci, zacierając różnicę między twórczością wernakularną a sztuką oraz popularną twórczością a działalnością komercyjną. Zob. Jean Burgess, Remediating Vernacular Creativity. Photography and Cultural Citizenship in the Flickr Photo-sharing Network
} 
cykl dziesięciu czarno-białych fotografii $\mathrm{w}$ formacie 4:5 przedstawia pojedyncze obiekty architektoniczne we frontalnym ujęciu, umieszczone symetrycznie w centrum kadru. Na sześciu fotografiach widzimy fasady drewnianych budynków, po jednym zdjęciu przypada na drogę śmierci w Birkenau, zbiornik wody na potrzeby kuchni obozowej, komorę do dezynfekcji pasiaków więźniarskich w budynku centralnej sauny oraz wagon bydlęcy na rampie w Birkenau. Cztery budynki stoją w byłym obozie Auschwitz I, a dwa w Birkenau. Seria jest spójna estetycznie, a w układzie zdjęć dostrzegam dbałość o narrację wizualną. Lakoniczne podpisy wskazują na funkcję danego budynku/obiektu w kompleksie obozowym. Z opisu projektu dowiadujemy się, że reguły rządzące zestawem obrazów zapożyczono od Bernda i Hilli Becher (mistrzów wizualnych klasyfikacji obiektów architektonicznych). Fotografie Lewandowskiego ilustrują zarówno zasadę architekta Louisa Sullivana „forma podąża za funkcją”, jak i obserwacje Zygmunta Baumana z Nowoczesności i Zagłady. Zdaniem fotografa „analiza typologiczna budynków i obiektów w tym cyklu fotograficznym pozwoli widzowi ocenić metody racjonalizacji architektury zaprojektowanej w celu sprawnego przeprowadzenia masowego mordu" 42 . Pod tym względem seria ta ma wymiar edukacji historycznej, skierowanej przede wszystkim do historyków architektury. Co istotne, pierwotną wersją są atramentowe wydruki na papierze barytowym (wielkoformatowe fotografie wykonano na czarno-białych negatywach $4 \times 5$ cali). Strona nie udostępnia żadnych metadanych, nie wiadomo, jak wielu internautów obejrzało te zdjęcia, brakuje tu narzędzi do wyrażania uznania przez odwiedzających. W odróżnieniu od innych portali dla fotografów nie znajdujemy tu metadanych fotograficznych (rodzaj sprzętu, ustawienia aparatu itp.). Zdjęcia prezentowane są jako pokaz slajdów, po jego zakończeniu pojawia się zachęta do ich udostępnienia na Facebooku i Twitterze.

Wygrana w tym konkursie nie jest jedynym wyróżnieniem dla Auschwitz Ultima Ratio of the Modern Age. W 2017 r. cykl wystawiono na Vintage Photo Festival w Bydgoszczy otrzymał także brązowy medal w konkursie NDAwards. Rok później zajął pierwsze miejsce w Moscow International Photography Awards w kategorii „architektura”. W 2019 r. 68 zdjęć z Auschwitz-Birkenau wydano $\mathrm{w}$ formie książkowej ${ }^{43}$ (ze strony fotografa dowiadujemy się, że fizycznie wystawiano zestaw 18, 27 lub 70 wydruków) ${ }^{44}$. Internetowy konkurs to alternatywny

[w:] Spaces of Vernacular Creativity. Rethinking the Cultural Economy, red. Tim Edensor i in., London, New York: Routledge, 2010, s. 116-125.

${ }^{42}$ Tomasz Lewandowski, Auschwitz - Ultima Ratio of the Modern Age, „lensculture.com”, brak daty, https://www.lensculture.com/search/projects?fallback=not-found\&q=auschwitz\&modal=project-522941-auschwitz-ultima-ratio-of-th (dostęp 10 VII 2021 r.).

${ }^{43}$ Tomasz Lewandowski, Auschwitz - Fall of the Modern Age, Halle: Mitteldeutscher Verlag, 2019. Nakład tej książki fotograficznej wynosi 800 egz.

${ }^{44}$ Tomasz Lewandowski, Auschwitz - Ultima Ratio of the Modern Age / 2017, „tomaszlewandowski.de", brak daty, https://www.tomaszlewandowski.de/lewandowski/auschwitz-ultima-ratio-of-the-modern-age/ (dostęp 10 VII 2021 r.). 
kanał dystrybucji projektu o niszowym zasięgu poza siecią, wysokich walorach estetycznych i intelektualnych. Wyróżnienie przez panel ekspertów jest ważniejsze od niejawnej liczby odsłon zdjęcia lub artykułu o projekcie na stronie głównej portalu ${ }^{45}$. Trzeba jednak zauważyć, że portal bardzo hojnie rozdaje nagrody i wyróżnienia, w 2017 r. jedynie w tym konkursie doceniono 50 fotografów i fotografek. Fotografowanie byłych obozów nie jest na tej platformie zbyt popularne, jurorzy zaś kierują się kryteriami estetycznymi, a nie historycznymi.

\section{Muzyczne lekcje dla ludzkości - Inge Ginsberg na portalu YouTube}

Cyfrowa rewolucja w dystrybucji muzyki odbywa się nie tylko w popularnych serwisach streamingowych, lecz także na platformie YouTube, co zdaniem przedstawicieli branży muzycznej doprowadziło do obniżenia wartości muzyki w sytuacji jej bezprecedensowej konsumpcji ${ }^{46}$. Początkowo badacze z optymizmem postrzegali wpływ tej platformy na rozwój kariery muzyków amatorów, wspominając o „efekcie YouTube” ${ }^{47}$. Nieprzejrzyste dla użytkowników zasady działania algorytmów oraz zmienna polityka wynagradzania twórców wprowadzają niepewność dotyczącą stabilności wynagrodzenia ${ }^{48}$. Chociaż rozliczenia finansowe z artystami są tajemnicą firmy, platforma udostępnia wiele metadanych świadczących o sukcesie danego materiału. Liczba odtworzeń jest tutaj najważniejszym wskaźnikiem ${ }^{49}$. Odtworzenie liczone jest po obejrzeniu przez użytkownika przynajmniej 30 sekund materiału. Romantyczna legenda sukcesu głosi, że dzięki platformie popularność zdobywają artyści spoza tradycyjnego biznesu muzycznego. Nie przekłada się to jednak na sukces komercyjny. Inną ścieżką kariery jest udział w telewizyjnych programach talentów ${ }^{50}$.

Inge Ginsberg wraz z zespołem The Tritone Kings wypróbowała obu tych dróg: produkcji teledysków na YouTube oraz przesłuchań w programach talen-

${ }^{45}$ Tomasz Lewandowski zdj. i tekst, Auschwitz: Ultima Ratio of the Modern Age , „Lensculture.com", brak daty, https://www.lensculture.com/articles/tomasz-lewandowski-auschwitzultima-ratio-of-the-modern-age (dostęp 13 VII 2021 r.).

${ }^{46}$ YouTube to ok. czterdzieści procent konsumpcji muzyki w sieci, lecz brak transparentności rozliczeń z wytwórniami, kompozytorami i wykonawcami sprawia, że rzesza muzyków nie otrzymuje godnej zapłaty. Zob. Michael Raine, YouTube. Friend or Foe of the Music Industry?, „Canadian Musician” 2017, May/June https://indepth.canadianmusician.com/youtubefriend-or-foe-of-the-music-industry/ (dostęp 12 VII 2021 r.).

${ }^{47}$ Christopher Cayari, The YouTube Effect. How YouTube Has Provided New Ways to Consume, Create, and Share Music, „International Journal of Education \& the Arts” 2011, t. 12, nr 6, s. 1-30.

${ }^{48}$ Sophie Bishop, Managing Visibility on YouTube through Algorithmic Gossip, „New Media \& Society" 2019, t. 21 nr 11/12, s. 2589-2606.

${ }^{49}$ Karin van Es, YouTube's Operational Logic. „The View” as Pervasive Category, „Television \& New Media" 2020, t. 21, nr 3, s. 223-239.

${ }^{50}$ Junhow Wei, "I'm the Next American Idol”. Cooling Out, Accounts, and Perseverance at Reality Talent Show Auditions, „Symbolic Interaction” 2016, t. 39, nr 1, s. 3-25. 
tów. Obecność na kanale YouTube rozpoczęła się od nagranej w 2014 r. piosenki Totenköpfchen (Laugh at Death) zgłoszonej w Szwajcarii do konkursu Eurowizji 2015, kolejny utwór Trümmer przygotowano na Eurowizję 2016. Dane dotyczące konkursów w 2015 i 2016 r. wskazują, że żadnej z tych propozycji nie wybrano w preselekcji ${ }^{51}$. W szwajcarskiej edycji Mam talent Ginsberg przedstawiła się: „moim największym talentem nie jest śpiewanie, lecz zdolność przeżycia”52. Pomysł występowania z zespołem metalowym - składającym się w istocie z klasycznie wykształconych muzyków - wyjaśnia krótko: „Nie potrafię śpiewać, nie trzymam tonacji. Metal mi odpowiada, bo wystarczy, że wypowiem słowa"53. Wokalistka (ur. 1922 r. w Wiedniu w rodzinie żydowskiej) nielegalnie przekroczyła granicę szwajcarską w 1942 r. W tym kraju pracowała jako szpieg dla amerykańskiego wywiadu, po wojnie zaś wraz z pierwszym mężem Ottem Kollmanem wyemigrowała do Stanów Zjednoczonych. W Hollywood tworzyli przeboje dla największych gwiazd lat pięćdziesiątych: Deana Martina, Doris Day i Nata Kinga Cole'a.

W tytułach teledysków podany jest wiek wokalistki i to, że jest babcią i ocalałą z Zagłady. Adresatami tych informacji są widzowie oraz algorytm platformy, zarządzający widzialnością treści, który w tytułach poszukuje słów kluczowych. Ginsberg jest autorką tekstów, a muzykę komponują Pedro H. da Silva i Lucía Caruso. Piosenki wykonywane są w języku niemieckim (z tłumaczeniem na angielski u dołu ekranu) i angielskim, teksty zaś poruszają tematy przemijania, odpowiedzialności człowieka za zniszczenie natury i sprzeciwu wobec niesprawiedliwości społecznych ${ }^{54}$. Nie mamy tutaj do czynienia z typowym świadectwem, lecz raczej z tzw. lekcjami dla ludzkości, niczym w sformalizowanych świadectwach wideo ocaleńców nagrywanych dla USC Shoah Foundation. Ten format znany jest zresztą Ginsberg, gdyż udzieliła wywiadu do tego archiwum w $1997 \mathrm{r}^{55} \mathrm{~W}$ odróżnieniu od innych użytkowników YouTube'a Ginsberg nie kieruje się chęcią zysku, lecz chciałaby, aby zauważono jej talent literacki. Dowodem uznania jest liczba wyświetleń (zob. przypisy). Jak podkreśla w krótko-

${ }^{51}$ Eurovision Song Contest 2015, „wikipedia.org”, brak daty, https://en.wikipedia.org/ wiki/Eurovision_Song_Contest_2015 i Eurovision Song Contest 2016, „wikipedia.org”, brak daty, https://en.wikipedia.org/wiki/Eurovision_Song_Contest_2016 (dostęp 16 VII 2021 r.).

${ }^{52}$ SRF Stadt Land Talent, Heavy Metal-Granny Inge Ginsberg rockt mit der Eigenkomposition Trümmer, „YouTube.com”, 20 II 2016, https://www.youtube.com/watch?v=Nr29SMyiM8M liczba odtworzeń 155746 (dostęp 3 VIII 2021 r.).

${ }^{53}$ Renee Ghert-Zand, 97-Year-Old Holocaust Survivor, Spy, and Heavy Metal Singer Is Ready to Rock You, „The Times of Israel”, 2 I 2019, https://www.timesofisrael.com/97-year-old-holocaust-survivor-spy-and-heavy-metal-singer-is-ready-to-rock-you/ (dostęp 14 VII 2021 r.).

${ }^{54}$ Jednoznaczne deklaracje polityczne znajdują się na marginesie tego apolitycznego gatunku. Zob. Niall Scott, Heavy Metal and the Deafening Threat of the Apolitical, „Popular Music History" 2011, t. 6, nr 1/2, s. 224-239.

${ }^{55}$ USC Visual History Archive (dalej USC VHA), 28527, Świadectwo Ingeborg Ginsberg, data nagrania 15 IV 1997 (wywiad w języku angielskim). 
metrażowym filmie dokumentalnym Death Metal Grandma (reż. Leah Galant, 2018), czuje się przede wszystkim poetką/pisarką, a nie muzykiem. Oglądając ten dokument, przekonujemy się, że kondycja psychofizyczna wokalistki uniemożliwia regularne występy na żywo: podczas przesłuchania do America's Got Talent zapomniała tekstu. Wbrew sugestii w tytule filmu ani Ginsberg nie jest wokalistką deathmetalową (nie posługuje się growlem ${ }^{56}$, lecz melorecytacją przechodzącą w krzyk), ani The Tritone Kings nie wykonują tej odmiany heavy metalu. Tempo jest zbyt wolne, perkusista nie korzysta z podwójnego pedału bębna basowego, a niestandardowa instrumentacja obejmuje syntezator, instrumenty smyczkowe i dęte. Występy wokalistów i wokalistek metalowych to nic nowego w programach talentów, w 2013 r. sześcioletnia Aaralyn podbiła serca widowni America's Got Talent wykonaniem skomponowanej przez siebie piosenki Zombie Skin ${ }^{57}$.

Wyprodukowane przez zespół teledyski zamieszczono na następujących kanałach ManhattanCamerata ${ }^{58}$ oraz Tritoneking ${ }^{59}$ prowadzonych przez instrumentalistów. Oba kanały mają niewielką subskrypcji, a popularność występów z Ginsberg nie zwiększyła liczby odsłon innych materiałów wideo. Reakcje pozytywne przeważają nad negatywnymi, a komentarze wyrażają uznanie dla odwagi Ginsberg oraz umiejętności instrumentalistów. Muzyczne występy Inge Ginsberg postrzegam jako szczególny przykład roli „ostatniego świadka”. Tym razem nie chodzi o przekazywanie wiedzy historycznej, lecz filozofii autentycznego życia. Te nagrania to tylko jedna z form publicznej aktywności Ginsberg, oprócz wspomnianego już wcześniej świadectwa wideo wydała bowiem wojenne wspomnienia przy współudziale Manfreda Flüggego w $2008 \mathrm{r}^{60}$

${ }^{56}$ Technika śpiewu w ekstremalnych odmianach metalu, polegająca na wydobywaniu dźwięku z pominięciem strun głosowych.

${ }^{57}$ America's Got Talent, 6-Year-Old Aaralyn Screams Her Original Song, „Zombie Skin” America's Got Talent, „YouTube.com”, 26 VI 2013, https://www.youtube.com/watch?v=VhQK-6il7cI liczba wyświetleń 44239341 (dostęp 28 VII 2021 r.).

${ }^{58}$ ManhattanCamerata, 93yo Metal Grandma Holocaust Survivor Spy! „Totenköpfchen” (Laugh at Death) - Swiss Eurovision 2015, „YouTube.com”, 31 X 2014, https://www.youtube.com/watch?v=TUxOnM0daAk liczba wyświetleń 763894 (dostęp 16 VII 2021 r.) oraz 96yo Metal Grandma Holocaust Survivor „The Universe Echoes Back” Inge Ginsberg \& the TritoneKings, „YouTube.com”, 18 VII 2018, https://www.youtube.com/watch?v=50utYNwpbKw liczba wyświetleń 158216 (dostęp 16 VII 2021 r.).

${ }^{59}$ Tritoneking, 94yo Heavy Metal Grandma Holocaust Survivor Spy! „Trümmer” The TritoneKings (Swiss Eurovision 2016), „YouTube.com”, 29 X 2015, https://www.youtube.com/ watch?v=ABKIQTKzY5U liczba wyświetleń 85724 (dostęp 16 VII 2021 r.) oraz Heavy metal granny Inge \& the TritoneKings rocks the stage with her own song „Trümmer”, „YouTube.com”, 20 II 2016, https://www.youtube.com/watch?v=pRLvbvhQ8KU liczba wyświetleń 21179 (dostęp 16 VII 2021 r.).

${ }^{60}$ Inge Ginsberg, Manfred Flügge, Die Partisanenvilla. Erinnerungen an Flucht, Geheimdienst und zahlreiche Schlager, München: Deutscher Taschenbuch Verlag, 2008. 


\section{Upamiętnianie w dobie platform cyfrowych}

Nie należy utożsamiać sukcesu odniesionego w ekonomii uwagi z sukcesem w polu upamiętniania Zagłady. To zastrzeżenie nie wynika bynajmniej z wrogości wobec mediów społecznościowych lub internetu ani z podważania wymiernych wskaźników (zasięgu, polubień, udostępnień). Warto przedefiniować, czym jest i czym powinno być upamiętnianie w ekosystemie mediów cyfrowych. Dostępne metadane nie służą do prostego porównania platform. Co więcej, trudność sprawia porównanie zasięgów na konkretnej platformie, np. YouTube. Jaki przyjąć punkt odniesienia? Inne zespoły muzyczne? Materiały historyczne przygotowane przez muzea Zagłady? Wywiady z ocaleńcami nagrane przez instytucjonalne programy historii mówionej lub przez członków rodziny? Czy w końcu przyjrzeć się influencerom, traktującym ten temat jako okazję dotarcia do nowych widzów? W tym artykule zestawiłem projekty artystyczne, a nie bardziej tradycyjne materiały edukacyjne lub poradniki, jak zwiedzać miejsca pamięci. Zysk w ekonomii uwagi zależy od segmentu rynku cyfrowego, na którym działa konkretny twórca. Liczba odtworzeń/udostępnień/polubień nie jest jedynym wyznacznikiem sukcesu. Te liczby wskazują jednak na konkretne zasięgi i reakcje publiczności. Wskaźniki nie określają wartości projektu w sferze upamiętniania, tu nadal sprawdzają się tradycyjne metody analizy treści, kryteria estetyczne i odniesienia do tradycyjnych form pamięci o Zagładzie. Skądinąd skupianie się na wymiernych wskaźnikach sukcesu wynika z logiki platform, na których zasięgi i odtworzenia są źródłem zysku ich właścicieli i niektórych użytkowników.

Tradycyjne formy cyfrowego upamiętniania skupione na opisie historycznym, archiwizacji i edukacji są przedłużeniem misji instytucji muzealnych. Twórcy treści niejednokrotnie podzielają to nastawienie, nie wiążą ich jednak zasady instytucjonalnego upamiętniania. Wychodzą także poza wąskie grupy odbiorców projektów historycznych. Skuteczne zarządzanie widzialnością treści nie ogranicza się do produkcji profesjonalnych lub historycznie poprawnych treści, lecz wymaga zrozumienia mechanizmów zdobywania i utrzymywania uwagi publiczności. Stąd cyfrowe upamiętnianie w mediach społecznościowych/na platformach rządzi się innymi prawami: twórcy kierują się powszechną rozpoznawalnością symboli Holokaustu (obozu Auschwitz-Birkenau lub współczesnych pomników), potrzebą uznania ich talentów, a nie kulturowymi nakazami zachowania pamięci.

Jedną ze słabości upamiętniania cyfrowego jest jego ulotność (brak archiwizacji, trudność z wyszukiwaniem, priorytet widoczności najnowszych treści w mediach społecznościowych itp.). Jak wyznaczyć horyzont czasowy powyższych projektów? Yolocaust to działanie interwencyjne, porzucone przez Shapirę po osiągnięciu wyznaczonych celów (ukaraniu sfotografowanych i wymuszeniu skruchy oraz autopromocji komika). Pierwotny pomysł wyklucza archiwizację zmodyfikowanych fotografii na stronie, to zadanie przejęły zewnętrzne platformy (wyszukiwarka obrazów Google i archiwum Wayback Machine). Liczba widzów 
projektu już nie wzrośnie. Fotografie Tomasza Lewandowskiego dotarły do widzów portalu w momencie ogłoszenia wyników konkursu i po zamieszczeniu artykułu o projekcie na stronie. Wysmakowana estetycznie fotografia analogowa skierowana jest zazwyczaj do wąskiego grona odbiorców. Z kolei obecny model biznesowy na platformie YouTube zakłada ciągły wzrost dostępności treści zauważonych przez algorytm, a odtworzenia muzyki nie maleją nawet po kilku latach od zamieszczenia teledysku. Tym samym nagrania z konkursów talentów i teledyski nadal będą znajdowały widzów. Z tego powodu występy Ginsberg mają najwyższą widzialność, znajdują się także w największym archiwum wideo na świecie.

Jakie są zalety i wady tych platform? Strona internetowa prowadzona przez pojedynczą osobę nie zasługuje na miano platformy, lecz sukces Shapiry zależał od udostępnień w mediach społecznościowych. Administrator strony ma dużą swobodę umieszczania treści, nie krępują go regulaminy platformy, nie chronią go jednak prawnicy przed ewentualnymi roszczeniami innych osób. Wyróżnienie w konkursie lensculture.com nie przekłada się na długofalowy wzrost widoczności danego projektu, $w$ istocie to fotograf powinien samodzielnie wyeksponować nagrodę. 0 ile twórca nie skasuje profilu lub platforma nie zaprzestanie działania, osobisty profil fotografa będzie jednym z miejsc archiwizacji. W odróżnieniu od innych mediów cyfrowych YouTube wykorzystuje (zmienne) algorytmy, podsuwając treści na podstawie historii wyszukiwania. YouTube ma schizofreniczną politykę jawności: udostępnianie danych o sukcesie danego materiału na platformie zderza się z nieprzejrzystością zmiennych zasad zarządzania widzialnością treści. Wobec odmiennego podejścia do wykorzystywania metadanych na różnych platformach niemożliwe jest ich bezpośrednie porównanie.

Nie wolno zapominać, że sukces treści w ekonomii uwagi to zysk korporacji - właścicieli platform cyfrowych (im większy ruch w sieci, tym więcej nadwyżki behawioralnej, tj. informacji o zachowaniach użytkowników, jak podkreśla Shoshana Zuboff). Wydarzenia historyczne o dużym ładunku emocjonalnym wywołują reakcje internautów, a te skrajne (prawicowy populizm, neofaszym, zaprzeczanie Zagładzie itp.) są w tym względzie źródłem zysku ${ }^{61}$. Z punktu widzenia korporacji cyfrowych treści są drugorzędne, bo liczy się liczba reakcji i udostępnień oraz innych aktywności użytkowników. W związku z tym zasadne jest pytanie, czy sukces upamiętniania zawdzięczamy platformom jako zdemokratyzowanym, nowym mediom, czy raczej wymaga on sabotowania niejawnej polityki tego modelu biznesowego. Mamy tu do czynienia z paradoksem: reguły upamiętniania wyznaczane są przez platformy o nieznanym profilu ideowym, gotowe sprzedać dane behawioralne zewnętrznym klientom, których interes może stać w sprzeczności z intencjami aktorów pamięci (np. targetowanie alt-prawicowych wyborców odszukanych przez algorytm na podstawie negatywnych komentarzy do materiałów upamiętniających Zagładę).

${ }^{61}$ Zuboff, Wiek kapitalizmu inwigilacji..., s. 160-161. Moderowane są jedynie treści odstraszające użytkowników lub rodzące ryzyko interwencji prawodawcy. 


\section{BIBLIOGRAFIA}

\section{Opracowania}

Anderson C.W. Practice, Interpretation, and Meaning in Today's Digital Media Ecosystem, „Journalism \& Mass Communication Quarterly" 2020, t. 97, nr 2.

Ashman Rachel, Anthony Patterson, Stephen Brown, 'Don't Forget to Like, Share and Subscribe.' Digital Autopreneurs in a Neoliberal World, „Journal of Business Research” 2018, t. 92.

Bareither Christoph, Difficult Heritage and Digital Media. 'Selfie Culture' and Emotional Practices at the Memorial to the Murdered Jews of Europe, „International Journal of Heritage Studies" 2021, t. 27, nr 1.

Bishop Sophie, Managing Visibility on YouTube through Algorithmic Gossip, „New Media \& Society" 2019, t. $21 \mathrm{nr} 11 / 12$.

Burgess Jean, Remediating Vernacular Creativity. Photography and Cultural Citizenship in the Flickr Photo-sharing Network [w:] Spaces of Vernacular Creativity. Rethinking the Cultural Economy, red. Tim Edensor i in. London, New York: Routledge, 2010.

Cayari Christopher, The YouTube Effect. How YouTube Has Provided New Ways to Consume, Create, and Share Music, „International Journal of Education \& the Arts" 2011, t. 12, nr 6, s. 1-30.

Citton Yves, The Ecology of Attention, Oxford: Polity, 2016.

Dalziel Imogen, Becoming the 'Holocaust Police'? The Auschwitz-Birkenau State Museum's Authority on Social Media [w:] Digital Holocaust Memory, Education and Research, red. Victoria Grace Walden. London: Palgrave MacMillan, 2021.

De Groot Jerome, Consuming History. Historians and Heritage in Contemporary Popular Culture, London: Routledge, 2016.

Dubrofsky Rachel E., Frayed Edges. Selfies, Auschwitz, and a Blushing Emoticon, „a/b: Auto/Biography Studies" 2018, t. 33, nr 3.

Duffy Brooke Erin, The Romance of Work. Gender and Aspirational Labour in the Digital Culture Industries, „International Journal of Cultural Studies” 2016, t. 19, nr 4.

Ebbrecht-Hartmann Tobias, Lital Henig, i-Memory. Selfies and Self-Witnessing in \#Uploading_Holocaust (2016) [w:] Digital Holocaust Memory, Education and Research, red. Victoria Grace Walden, London: Palgrave MacMillan, 2021.

Eichhorn Kate, The End of Forgetting. Growing up with Social Media, Cambridge, MA: Harvard University Press, 2019.

Gallardo Kristine L., Taming the Internet Pitchfork Mob. Online Public Shaming, the Viral Media Age, and the Communications Decency Act, „Vanderbilt Journal of Entertainment and Technology Law" 2017, t. 19, nr 3.

Ginsberg Inge, Manfred Flügge, Die Partisanenvilla. Erinnerungen an Flucht, Geheimdienst und zahlreiche Schlager. München: Deutscher Taschenbuch Verlag, 2008.

Goldberg Greg, Antisocial Media: Anxious Labor in the Digital Economy, New York: NYU Press, 2018.

Kozinets Robert V., Netnografia: badania etnograficzne online, tłum. Maja Brzozowska-Brywczyńska, Warszawa: Wydawnictwo Naukowe PWN, 2012.

Kozinets Robert V., Daiane Scaraboto, Marie-Agnès Parmentier, Evolving Netnography. How Brand Auto-netnography, a Netnographic Sensibility, and More-than-human Netnography Can Transform Your Research, „Journal of Marketing Management” 2018, t. 34, nr 3/4.

Lewandowski Tomasz, Auschwitz - Fall of the Modern Age, Halle: Mitteldeutscher Verlag, 2019. 
Łysak Tomasz, Kultura popularna [w:] Reprezentacje Zagłady w kulturze polskiej (19392019), t. 2: Problematyka Zagłady w sztukach wizualnych i popkulturze, red. Sławomir Buryła, Dorota Krawczyńska, Jacek Leociak, Warszawa: Wydawnictwo IBL PAN, 2021.

Łysak Tomasz, Vlogging Auschwitz. New Players in Holocaust Commemoration, „Holocaust Studies: A Journal of Culture and History" 2021, w przygotowaniu.

Milbrandt Tara, Caught on Camera, Posted Online. Mediated Moralities, Visual Politics and the Case of Urban 'Drought-Shaming', „Visual Studies” 2017, t. 32, nr 1.

Mirzoeff Nicholas, Jak zobaczyć świat, tłum. Łukasz Zaremba, Kraków-Warszawa: Wydawnictwo Karakter, Muzeum Sztuki Współczesnej w Warszawie, 2016.

Netnography Unlimited, red. Robert V. Kozinets, Rossella Gambetti. New York: Routledge, 2020.

Pomerantz Jeffrey, Metadata, Cambridge, MA: The MIT Press, 2015.

Raine Michael, YouTube. Friend or Foe of the Music Industry?, „Canadian Musician” 2017, May/June https://indepth.canadianmusician.com/youtube-friend-or-foe-of-themusic-industry/.

Scott Niall, Heavy Metal and the Deafening Threat of the Apolitical, „Popular Music History" 2011, t. 6 , nr $1 / 2$.

Smiley Calvin John, From Silence to Propagation. Understanding the Relationship between „Stop Snitchin” and „YOLO”, „Deviant Behavior” 2015, t. 36, nr 1.

Sorell Tom, Scambaiting on the Spectrum of Digilantism, „Criminal Justice Ethics” 2019, t. 38, nr 3 .

Srnicek Nick, Platform Capitalism. Cambridge: Polity, 2017.

Van Es Karin, YouTube's Operational Logic. „The View” as Pervasive Category, „Television \& New Media" 2020, t. 21, nr 3.

Walden Victoria Grace, Introduction. Defining the Digital in Digital Holocaust Memory, Education, and Research [w:] Digital Holocaust Memory, Education and Research, red. Victoria Grace Walden, London: Palgrave MacMillan, 2021.

Wei Junhow, „I'm the Next American Idol”. Cooling Out, Accounts, and Perseverance at Reality Talent Show Auditions, „Symbolic Interaction” 2016, t. 39, nr 1.

Williams Penny, Paula McDonald, Robyn Mayes, The Impact of Disruptive Innovation on Creative Workers. The Case of Photographers, „Creative Industries Journal” 2020, doi.org/10.1080/17510694.2020.1858707.

Zuboff Shoshana, Wiek kapitalizmu inwigilacji: walka o przyszłość ludzkości na nowej granicy władzy, tłum. Alicja Unterschuetz, Poznań: Zysk i S-ka, 2020.

\section{Netografia}

America's Got Talent, 6-Year-Old Aaralyn Screams Her Original Song, „Zombie Skin” America's Got Talent, „YouTube.com”, 26 VI 2013, https://www.youtube.com/ watch?v=VhQK-6iI7cI liczba wyświetleń 44239341.

Eurovision Song Contest 2015, brak autora, „wikipedia.org”, brak daty, https:/ /en.wikipedia.org/wiki/Eurovision_Song_Contest_2015.

Eurovision Song Contest 2016, brak autora, „wikipedia.org”, brak daty, https://en.wikipedia.org/wiki/Eurovision_Song_Contest_2016.

Kaze Jhony Feat Snippah, „Yolocaust” - Prod by Essem - Offizielles HD Video, „YouTube”, 20 III 2014, https://www.youtube.com/watch?v=KXZgq7QDeXY.

Lewandowski Tomasz, zdj. i tekst, Auschwitz: Ultima Ratio of the Modern Age, „Lensculture.com”, brak daty, https://www.lensculture.com/articles/tomasz-lewandowski-auschwitz-ultima-ratio-of-the-modern-age. 
Lewandowski Tomasz, Auschwitz - Ultima Ratio of the Modern Age, „lensculture.com”, brak daty, https://www.lensculture.com/projects/522941-auschwitz-ultima-ratio-of-th.

Lewandowski Tomasz, Auschwitz - Ultima Ratio of the Modern Age / 2017, „tomaszlewandowski.de", brak daty, https://www.tomaszlewandowski.de/lewandowski/ auschwitz-ultima-ratio-of-the-modern-age/.

MAKJ Causes Uproar With Controversial Photo Taken at Berlin Holocaust Memorial, brak autora, „Thissongslaps.com”, 28 VIII 2014, https://www.thissongslaps. com/2014/08/makj-causes-uproar-with-controversial-photo-taken-at-berlinholocaust-memorial/.

ManhattanCamerata, 93yo Metal Grandma Holocaust Survivor Spy! „Totenköpfchen” (Laugh at Death) -Swiss Eurovision 2015, „YouTube.com”, 31 X 2014, https://www. youtube.com/watch?v=TUxOnM0daAk.

ManhattanCamerata, 96yo Metal Grandma Holocaust Survivor „The Universe Echoes Back” Inge Ginsberg \& the TritoneKings, „YouTube.com”, 18 VII 2018, https://www.youtube.com/watch?v=50utYNwpbKw.

Orzechowski Hubert, Yolocaust. Pomyśl, zanim zrobisz selfie, „Newsweek”, 20 I 2017, https:// www.newsweek.pl/kultura/wydarzenia/yolocaust-co-to-jest-selfie-w-miejscachpamieci-zaglady/1we1mkr.

SRF Stadt Land Talent, Heavy Metal-Granny Inge Ginsberg rockt mit der Eigenkomposition Trümmer, „YouTube.com”, 20 II 2016, https://www.youtube.com/ watch?v=Nr29SMyiM8M.

Tritoneking, 94yo Heavy Metal Grandma Holocaust Survivor Spy! „Trümmer” The TritoneKings (Swiss Eurovision 2016), „YouTube.com”, 29 X 2015, https://www.youtube.com/watch?v=ABKIQTKzY5U.

Tritoneking, Heavy metal granny Inge \& the TritoneKings rocks the stage with her own song „Trümmer”, „YouTube.com”, 20 II 2016, https://www.youtube.com/ watch?v=pRLvbvhQ8KU.

Watemborski Marcin, Yolocaust to selfie na szczq̨tkach ofiar holocaustu. Mocna seria zdjęć obnażajaca brak szacunku dla ludzkiej tragedii, „Fotoblogia”, brak daty, https:// fotoblogia.pl/10144,yolocaust-co-jest-wazniejsze-selfie-czy-szacunek-dla-ludzkiej-tragedii. 